\title{
Performance of Two Simulated Green Roofs in the Mediterranean Area
}

\author{
Antonio Vestrella ${ }^{1}$, Robert Savé ${ }^{1} \&$ Carmen Biel $^{1}$ \\ ${ }^{1}$ IRTA (Research and Technology, Food and Agriculture Institute), Barcelona, Spain \\ Correspondence: Antonio Vestrella, IRTA (Research and Technology, Food and Agriculture Institute), Torre \\ Marimon 08140 Caldes de Montbui, Barcelona, Spain. Tel: 34-934-674-040. Fax: 34-93-865-0954. E-mail: \\ antoniovestrella@gmail.com
}

\author{
Received: August 1, 2015 Accepted: September 2, 2015 Online Published: October 15, 2015 \\ doi:10.5539/jas.v7n11p59 URL: http://dx.doi.org/10.5539/jas.v7n11p59
}

\begin{abstract}
The green roofs sector is a relatively recent phenomenon in Mediterranean countries, meaning that as yet there is no complete understanding of which plants are suited to this particular environment. Such plants would need to be adaptable to the green roof itself as well as to the drought and intense lighting typical of a Mediterranean summer. Two simulated green roofs were planted with a variety of species and life forms and subjected to two minimal irrigation treatments and one treatment without irrigation. Mainly subshrub species were planted in one simulation, while the other contained a prevalence of groundcover species. The study looked at performance in terms of species, life forms, and simulation. We analysed flowering, mortality, frequency of planted species and of invasive species, and biomass. We took periodic measurements of cover and of the Shannon-Wiener vegetal diversity index. The groundcover species obtained a higher degree of cover, but suffered more from seasonal stresses. Both green roofs saw an increase in the abundance of a few species, leading to a simplification of the original design. Diversity and the ability to host colonising species were influenced mainly by differences in vegetational structure. Of the subshrub species, Centranthus ruber and Helichrysum stoechas performed best, while Frankenia laevis and Thymus serpyllum came top among groundcover species. In order to withstand severe drought stress, a minimal amount of irrigation was found to be necessary. Our study demonstrates that it is possible to obtain good results from a Mediterranean green roof by using an appropriate combination of vegetal species with different structures and development.
\end{abstract}

Keywords: coverage, diversity, drought stress, flowering, green roofs, mortality, vegetation structure

\section{Introduction}

Green roofs represent an ideal opportunity to improve the urban environment. They increase biodiversity in cities (Lundholm, 2006; Oberndorfer et al., 2007; Bass, 2009), lead to reduced energy costs for the buildings on which they are installed (Liu \& Baskaran, 2003; Carter \& Butler, 2008; Spala et al., 2008), and by absorbing rainwater they reduce stormwater runoff and the consequent overloading of drainage systems (Liu \& Minor, 2005; Mentens et al., 2006; Stovin, 2010). The green roofs sector in Northern Europe has experienced more rapid development than its Mediterranean counterpart, and yet the Mediterranean area could benefit enormously from this technology (Benvenuti \& Bacci, 2010; Ekşi \& Uzun, 2013; Van Mechelen et al., 2014). The delay in implementing green roofs technology is related to specific climate conditions in the Mediterranean area, including high temperatures and prolonged droughts. Global warming could see temperatures rising both locally and across the entire area, and predicted climate changes mean that the Mediterranean area could benefit from the effects of increased vegetational cover (IPCC, 2013; Sheffield \& Wood, 2008).

It is reasonable to assume that these negative effects will be felt even more in cities, due to increases in energy consumption and the urban heat island effect. In many large cities, including London and Hong Kong, green roofs are seen as an important instrument in the urban planner's attempts to combat the aforementioned effects (Townshend \& Duggie, 2007; Greater London Authority, 2008; Van Lennep \& Finn, 2008).

In the Mediterranean area, Barcelona has for years been working on projects aimed at improving the ecological connectivity of its urban spaces. One of these projects involves the use of green roofs and walls to create urban green corridors which will preserve a link between the city and surrounding natural environments (Àrea de Medi Ambient, Ajuntament de Barcelona, 2010, 2011). 
One important characteristic of green roofs is that they improve public perceptions of the urban environment. This addresses one of the most deeply felt problems of city living, where the lack or scarcity of natural environments transforms inhabitant's appreciation of natural processes (Benvenuti, 2014). It is predicted that urban populations will increase in future decades, leading to a reduction in the space set aside for natural areas. This reduction can in part be countered by creating green habitats on the roofs of buildings. Benvenuti (2014) has trialled the performance of a number of wild flowers typical of Mediterranean landscapes with a green roof simulation designed to evaluate their biodiversity dynamics and bio-agronomic performance, going on to propose that they be used in green roofs in order to re-establish a relationship with the natural world and its seasonal variations.

The technical and cultural challenges represented by differences in climate conditions and urban settings mean that it is fundamental that more research be carried out to identify the species which are most adaptable to green roof environments in a Mediterranean climate and at the same time are able to withstand possible water shortages in the future. There have been a number of studies on the development of green roof vegetation over reasonably long periods, many of them concluding that plant diversity is dependent on the properties of the substrate (Bates et al., 2013; Thuring \& Dunnett, 2014). Other studies have identified a relationship between the evolution of vegetation and the availability of water, as well as the depth of the substrate (Dunnett \& Nolan, 2004; Getter \& Rowe, 2009; Rowe et al., 2012).

The aim of this study was to analyse the performance of two simulated green roofs, each with different arrangements of plants, in a Mediterranean environment over a period of eighteen months. An arrangement of plants dominated by groundcover species and another dominated by subshrub species were each subjected to two different minimal irrigation protocols and to one protocol where the only water source was from rainfall. For the purposes of this study a number of agronomic, aesthetic, and functional parameters were recorded.

\section{Materials and Methods}

\subsection{Study Site}

The study took place between July 2010 and December 2011 at the IRTA (Institute for the Research of Food \& Agricultural Technologies) in Caldes di Montbui (205 metres above sea level, 41 $\left.{ }^{\circ} 63^{\prime} \mathrm{N} 2^{\circ} 16^{\prime} \mathrm{E}\right), 30 \mathrm{~km}$ from Barcelona in Spain, along a Mediterranean coastal mountain range. Table 1 shows the principle climate data as measured during the study period, and Table 2 gives an overview of climate figures for the twenty years preceding this study.

Table 1. Monthly averages for the principle meteorological parameters during the study period (July 2010-December 2011) recorded at the Caldes de Montbui weather station (Barcelona)

\begin{tabular}{llllll}
\hline & \multicolumn{3}{c}{ Temp. $\left({ }^{\circ} \mathrm{C}\right)$} & Rainfall $(\mathrm{mm})$ & $\mathrm{Et}_{\mathrm{o}}(\mathrm{mm})$ \\
\cline { 2 - 4 } & Mean & Min. recorded & Max. recorded & & \\
\hline July 2010 & 25.1 & 16.9 & 35.6 & 37.9 & 166.7 \\
August 2010 & 23.5 & 14.6 & 37.9 & 47.3 & 141.5 \\
September 2010 & 19.9 & 10.8 & 31.4 & 82.6 & 92.3 \\
October 2010 & 14.9 & 1.5 & 25.9 & 136.5 & 64.6 \\
November 2010 & 9.1 & -2.5 & 22.9 & 15.3 & 38.5 \\
December 2010 & 6.4 & -4.4 & 20.0 & 47.7 & 25.3 \\
January 2011 & 6.5 & -6.3 & 19.7 & 28.8 & 31.3 \\
February 2011 & 7.7 & -2.2 & 21.1 & 16.1 & 41.4 \\
March 2011 & 9.9 & -1.3 & 21.6 & 193.0 & 64.5 \\
April 2011 & 14.8 & 4.9 & 29.9 & 31.3 & 103.3 \\
May. 2011 & 17.8 & 7.0 & 31.2 & 67.4 & 138.8 \\
June 2011 & 20.1 & 10.2 & 31.9 & 70.3 & 134.1 \\
\hline
\end{tabular}




\begin{tabular}{llllll}
\hline July 2011 & 21.7 & 12.7 & 31.9 & 88.2 & 131.4 \\
August 2011 & 23.4 & 13.8 & 34.6 & 10.4 & 146.5 \\
September 2011 & 21.3 & 9.5 & 30.9 & 4.8 & 110.5 \\
October 2011 & 16.7 & 4.5 & 31.7 & 69.3 & 73.5 \\
November 2011 & 12.7 & 2.5 & 20.9 & 190.7 & 30.4 \\
December 2011 & 7.4 & -2.4 & 16.7 & 1.0 & 30.4 \\
\hline
\end{tabular}

Table 2. Average climate figures recorded over a twenty years period at the study site* (average for each year from 1991 to 2010)

\begin{tabular}{|c|c|c|c|c|c|c|c|}
\hline \multirow{2}{*}{ Year } & \multicolumn{3}{|c|}{ Temp. $\left({ }^{\circ} \mathrm{C}\right)$} & \multirow{2}{*}{-Rainfall (mm) } & \multirow{2}{*}{$\mathrm{ET}_{0}(\mathrm{~mm})$} & \multirow{2}{*}{ Number of rainy days } & \multirow{2}{*}{ Number of days $<0{ }^{\circ} \mathrm{C}$} \\
\hline & Mean & Max & Min & & & & \\
\hline 1991 & 13.2 & 19.3 & 7.6 & & & & \\
\hline 1992 & 13.9 & 20.1 & 8.5 & 688.8 & 596.5 & 157 & 39 \\
\hline 1993 & 13.9 & 20.3 & 8.4 & 625.0 & 816.3 & 179 & 41 \\
\hline 1994 & 14.9 & 21.6 & 8.8 & 607.4 & 871.9 & 144 & 36 \\
\hline 1995 & 14.7 & 21.1 & 8.7 & 520.8 & 803.4 & 163 & 21 \\
\hline 1996 & 11.1 & 16.0 & 6.2 & 953.8 & 757.8 & 180 & 41 \\
\hline 1997 & 15.1 & 21.6 & 9.3 & 592.7 & 838.2 & 141 & 15 \\
\hline 1998 & 14.4 & 21.1 & 8.4 & 471.8 & 886.5 & 119 & 42 \\
\hline 1999 & 14.5 & 21.3 & 8.4 & 473.6 & 806.1 & 119 & 50 \\
\hline 2000 & 14.7 & 21.4 & 8.7 & 542.6 & 799.1 & 145 & 30 \\
\hline 2001 & 15.0 & 21.7 & 8.9 & 280.4 & 877.3 & 143 & 32 \\
\hline 2002 & 14.7 & 21.1 & 8.9 & 656.6 & 845.5 & 160 & 17 \\
\hline 2003 & 15.4 & 22.0 & 9.4 & 551.6 & 882.0 & 138 & 36 \\
\hline 2004 & 14.5 & 21.2 & 8.5 & 497.0 & 758.4 & 133 & 39 \\
\hline 2005 & 14.1 & 20.9 & 8.0 & 611.0 & 925.2 & 140 & 83 \\
\hline 2006 & 15.4 & 22.2 & 9.4 & 682.0 & 890.6 & 137 & 36 \\
\hline 2007 & 15.1 & 22.4 & 9.0 & 405.3 & 806.6 & 71 & 23 \\
\hline 2008 & 14.8 & 21.5 & 9.0 & 741.0 & 988.3 & 112 & 18 \\
\hline 2009 & 15.2 & 22.1 & 9.2 & 541.9 & 1065.0 & 96 & 21 \\
\hline 2010 & 14.2 & 15.6 & 12.9 & 743.0 & 998.5 & 29 & 21 \\
\hline
\end{tabular}

Note. * data from the Caldes de Montbui weather station (MeteoCat http://www.meteo.cat/servmet/radar/).

\subsection{Green Roof System}

Each of the two simulated green roofs was planted with different combinations of species: one contained a majority of groundcover species, the other mostly subshrubs. Each green roof had a surface area of $54 \mathrm{~m}^{2}$ divided into nine subplots measuring $6 \mathrm{~m}^{2}$ each, three subplots for each irrigation treatment. Firstly the base of the structure was covered with a root barrier membrane and a polyethylene mat which served as a foundation upon which to build a ZinCo ${ }^{\circledR}$ system for extensive green roofs. The base layer of the system was an SSM 45 protection mat with an approximate water absorption capacity of $5 \mathrm{l} / \mathrm{m}^{2}$. The protection mat was covered with a Floradrain ${ }^{\mathbb{R}} \mathrm{FD} 25$-E drainage and water storage element made of thermoformed recycled polyethylene with a storage capacity of approximately $10 \mathrm{l} / \mathrm{m}^{2}$. The third layer was an SF thermally strengthened filter sheet made of polypropylene, followed by a 'Floral' type Zincoterra substrate (ZinCo Product List).

The floral substrate had an organic material content of approximately $5 \%$, a bulk density value of 0.9 , and $66 \%$ total porosity. $\mathrm{pH}$ values varied between 8.08 and 8.29 while electrical conductivity values ranged from 156.1 to 


\section{$155.9 \mu \mathrm{S} / \mathrm{cm}$ (microSiemens/cm).}

\subsection{Experimental Design and Plant Selection}

The number, arrangement and selection of species in each simulation were based on results obtained from a previous study carried out under the same conditions which analysed various parameters including coverage trend, biomass, and mortality (Vestrella et al., 2015). The experiment was performed using groundcover and subshrub species. Three plots were planted for each of the three irrigation protocols for a total of nine plots. Each of the nine main plots had a surface area of $12 \mathrm{~m}^{2}$ which was divided into two sub-plots of $6 \mathrm{~m}^{2}$ each $(2 \times 6 \mathrm{~m})$. 61 plants representing 8 species were planted in each subshrub subplot, resulting in a density of 10 plants per square meter. 59 plants of 6 species were planted in each groundcover subplot, resulting in a density of 10 plants per square meter. The placement of the species was the same for every plot in each irrigation protocol. Plants in the subshrub subplots were placed randomly, although care was taken to ensure that each square metre contained at least one plant of each species. In the groundcover species subplots the plants were arranged in a grid, where one of two groundcover species (Dymondia margaretae and Frankenia laevis) was planted at each intersection of the grid. Another four species were planted inside the grid squares. Table 3 provides a list of the species used in the two green roof simulations, figure 1 shows the arrangement and layout of the plants.

Table 3. Species used in the two green roof simulations with number of plants for each species and common English names

\begin{tabular}{|c|c|c|c|}
\hline \multicolumn{2}{|l|}{ Green roof with subshrubs } & \multicolumn{2}{|l|}{ Green roof with groundcover } \\
\hline Species & Number of plants & Species & Number of plants \\
\hline $\begin{array}{l}\text { Helichrysum stoechas (L.) Moench } \\
\text { Common shubbry everlasting }\end{array}$ & 10 & $\begin{array}{l}\text { Frankenia laevis L. } \\
\text { Sea heath }\end{array}$ & 17 \\
\hline $\begin{array}{l}\text { Santolina rosmarinifolia } \mathrm{L} . \\
\text { Green lavander cotton }\end{array}$ & 10 & $\begin{array}{l}\text { Dymondia margaretae Compton } \\
\text { Silver carpet }\end{array}$ & 18 \\
\hline $\begin{array}{l}\text { Drosanthemum floribundum (Haw.) } \\
\text { Schwantes. } \\
\text { Pale dew-plant }\end{array}$ & 5 & $\begin{array}{l}\text { Limonium virgatum (Willd.) Fourr. } \\
\text { Violeta sea lavender }\end{array}$ & 6 \\
\hline $\begin{array}{l}\text { Armeria maritima (P. Mill.) Willd. } \\
\text { Sea thrift }\end{array}$ & 11 & $\begin{array}{l}\text { Thymus serpyllum L. } \\
\text { Breckland Thyme }\end{array}$ & 6 \\
\hline $\begin{array}{l}\text { Lotus creticus L. } \\
\text { Creta trefoil }\end{array}$ & 5 & $\begin{array}{l}\text { Drosanthemum floribundum (Haw.) } \\
\text { Schwantes } \\
\text { Pale dew-plant }\end{array}$ & 6 \\
\hline $\begin{array}{l}\text { Centranthus ruber (L.) DC. } \\
\text { Red valerian }\end{array}$ & 5 & $\begin{array}{l}\text { Asteriscus maritimus (L.) Less. } \\
\text { Sea daisy }\end{array}$ & 6 \\
\hline $\begin{array}{l}\text { Asteriscus maritimus (L.) Less. } \\
\text { Sea daisy }\end{array}$ & 5 & & \\
\hline $\begin{array}{l}\text { Iris lutescens Lam. } \\
\text { Crimean iris }\end{array}$ & 10 & & \\
\hline & Total: 61 & & Total: 59 \\
\hline
\end{tabular}



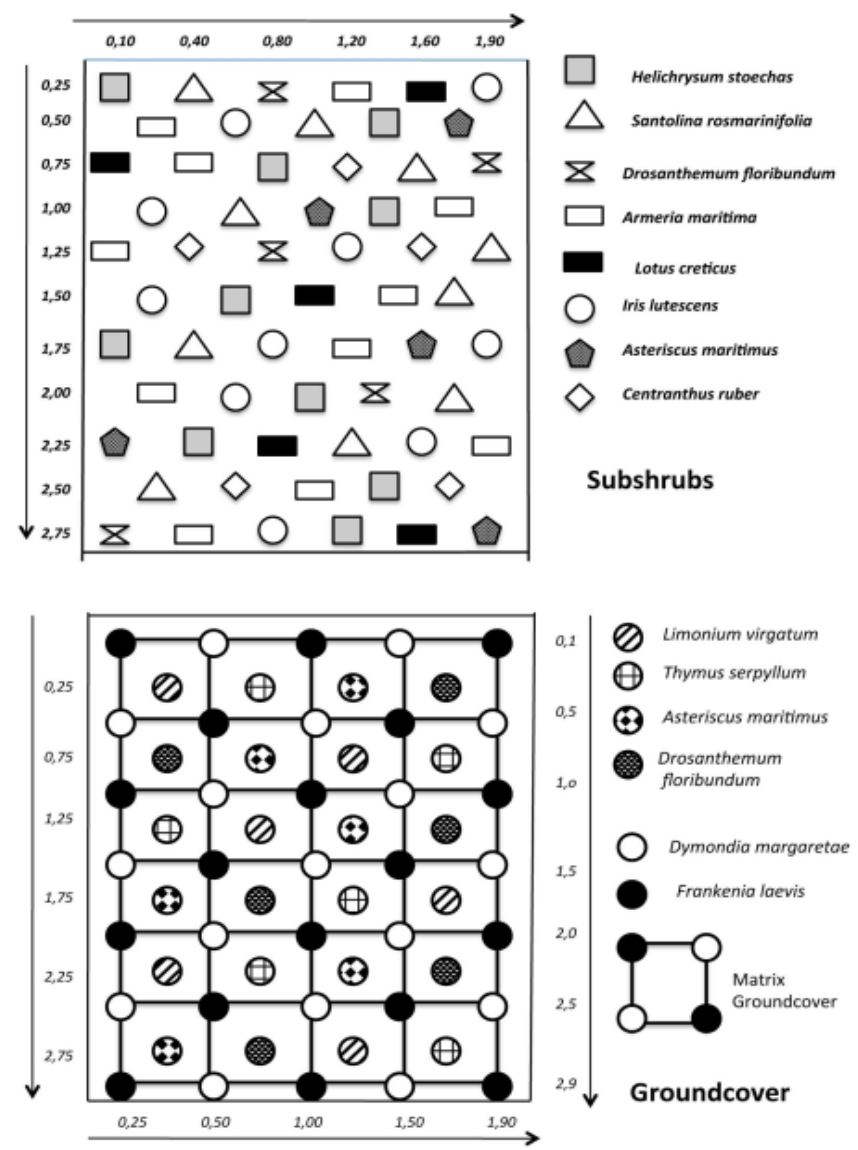

Figure 1. Arrangement of plants according to species, showing layout and distances

\subsection{Irrigation}

Three different irrigation protocols were used: rainfed (no use of artificial irrigation, $0 \% \mathrm{ET}_{0}$ ); resupply of $20 \%$ of water lost to potential evotranspiration $\left(20 \% \mathrm{ET}_{0}\right)$; and resupply of $40 \%$ of the same $\left(40 \% \mathrm{ET}_{0}\right)$. Potential evotranspiration $\left(\mathrm{ET}_{0}\right)$ was calculated at the Caldes de Montbui weather station two hundred metres from the study site. Each week a calculation was made of how much water to supply to the plants by subtracting the total amount of precipitation during the previous week from the total value of $\mathrm{ET}_{0}$. The resulting amount of water was distributed evenly throughout the week. Water was supplied by drip emitting tubes placed on the surface of the soil. The tubes were placed at a distance of $40 \mathrm{~cm}$ from each other and had a diameter of $16 \mathrm{~mm}$ with a flow rate of 22.8 litres $\mathrm{m}^{-2}$ hour $^{-1}$.

\subsection{Green Roof Measurements}

The following parameters were measured: percentage of mortality, vegetational cover of soil, flowering, final biomass of roots and of upper sections. Vegetational diversity trends were calculated, as well as the presence of single species throughout the trial, taking into account colonising species as well as those which were intentionally planted. Measurements were taken for each individual species and for the green roof as a whole.

Plant mortality was recorded each month. Plants without living stems or leaves were considered dead even though they were left in place so as to observe any appearance of new shoots.

Green cover was measured using a Nikon EOS 500 digital camera mounted on a tripod, and a laptop computer running the Greenpix software developed by the IRTA (Institute for Food and Agricultural Research and Technology) for the analysis of digital imagery (Casadesús et al., 2005, 2007). The green roof was photographed once a month using an $18 \mathrm{~mm}$ lens mounted on a tripod arm $2.5 \mathrm{~m}$ from the ground. The camera was connected to a laptop running Nikon EOS software, making it possible to remotely adjust the image and activate the shutter. Diaphragm aperture remained constant throughout, and the photographs were taken between $11 \mathrm{am}$ and $2 \mathrm{pm}$ so as to avoid long shadows.

The images were then processed with the Greenpix software. This software makes it possible to identify colour 
variations between pixels within a $0^{\circ}$ to $180^{\circ}$ hue range. It is possible within this range to calculate the number of yellow, green, and brown pixels and the percentage of total pixels represented by each colour. The surface area represented by each pixel was calculated and translated into square centimetres so as to obtain the total surface area for each plant colour.

Total plant cover surface was calculated by identifying all pixels between $40^{\circ}$ and $180^{\circ}$, equivalent to green and some brown tones.

Duration of flowering was calculated for each green roof and for all species by making monthly observations during the first year and every fifteen days from April to October of the second year. Biomass was measured on completion of the study period by removing the plants from the soil, cleaning them, and placing them in a ventilated oven at $65^{\circ}$ centigrade for seven days. Roots and upper sections were then weighed separately.

The presence of each species in the green roofs was measured every two months by superimposing a grid onto the photographs used to measure vegetational cover. Photoshop CS was used to place a grid of 96 nodes on a photograph of each of the three repetitions of irrigation treatments. The species of plants present at each node, or grid intersection, were recorded. Species identifications made using the photographs was then verified on site.

The results thus obtained made it possible to calculate the presence of each species in each subplot, as well as the presence of colonising species in order to understand how they influenced the evolution of the two green roofs. We were likewise able to calculate the diversity index by applying the Shannon Wiener formula:

$$
\text { Diversity }\left(H^{\prime}\right)=-S(n i / N) \times \ln (n i / N)
$$

This index is based on the amount of species in each subplot (richness) and the number of plants of each species (abundance). The index is relative and indicates the degree of difference or similarity between different specimens. In our study the values recorded in July 2010 represent the initial values, or those which correspond to vegetational diversity at the moment of planting in the two green roofs. The initial value of the subshrubs section was higher because a greater number of species were planted (Table 3 ).

\subsection{Statistical Analysis}

The experiment was a factorial design with three factors: irrigation treatment, sampling date and subplot. The mixed model used for analysing the plant cover in each green roof included the following fixed effects: sampling date, irrigation treatments and the interaction between sampling date and irrigation, whereas the random effects were subplots and the interaction between subplot and irrigation. Three levels were set for irrigation, seventeen for sampling date and three for the subplots. The Tukey pairwise comparison post-hoc test was used to identify mean values that were different with a probability of 0.05 or less in the main factors (irrigation and sampling date). To compare irrigation treatments for a single sampling date, a slice was performed on the interaction by sampling date when interactions were significant. The analysis was carried out using the SAS 9.4 software. Average mortality rates, total cover, and biomass for each irrigation treatment and both green roof simulations were compared using the Tukey Kramer HSD test and JMP 10 software.

\section{Results}

\subsection{Mortality}

Figure 2 shows mortality trends throughout the study period. The highest final mortality rates in both green roofs were registered for the areas with no artificial irrigation. There were no significant differences in average mortality rates between the three different irrigation treatments in the subshrub green roof. For the groundcover green roof, average mortality rates in the irrigated sections were significantly (significance level $\mathrm{P}<0.05$ ) different from those of the plants which received no irrigation (Table 4).

Table 4. Average mortality percentages throughout the entire study period for the three irrigation treatments $(0 \%$, $20 \%$ and $40 \% \mathrm{ET}_{0}$ ) in both green roofs (subshrubs and groundcover). Comparison between average percentages was made using the Tukey-Kramer HSD Test (significance level $\mathrm{P}<0.05$ ). Significant differences in data are represented by different alphabetical letters

\begin{tabular}{lll}
\hline & Subshrubs & Groundcover \\
\hline $0 \% \mathrm{ET}_{0}$ & $47,397 \mathrm{~A}$ & $47,352 \mathrm{~A}$ \\
$20 \% \mathrm{ET}_{0}$ & $41,632 \mathrm{~A}$ & $24,833 \mathrm{~B}$ \\
$40 \% \mathrm{ET}_{0}$ & $41,014 \mathrm{~A}$ & $21,529 \mathrm{~B}$ \\
\hline
\end{tabular}



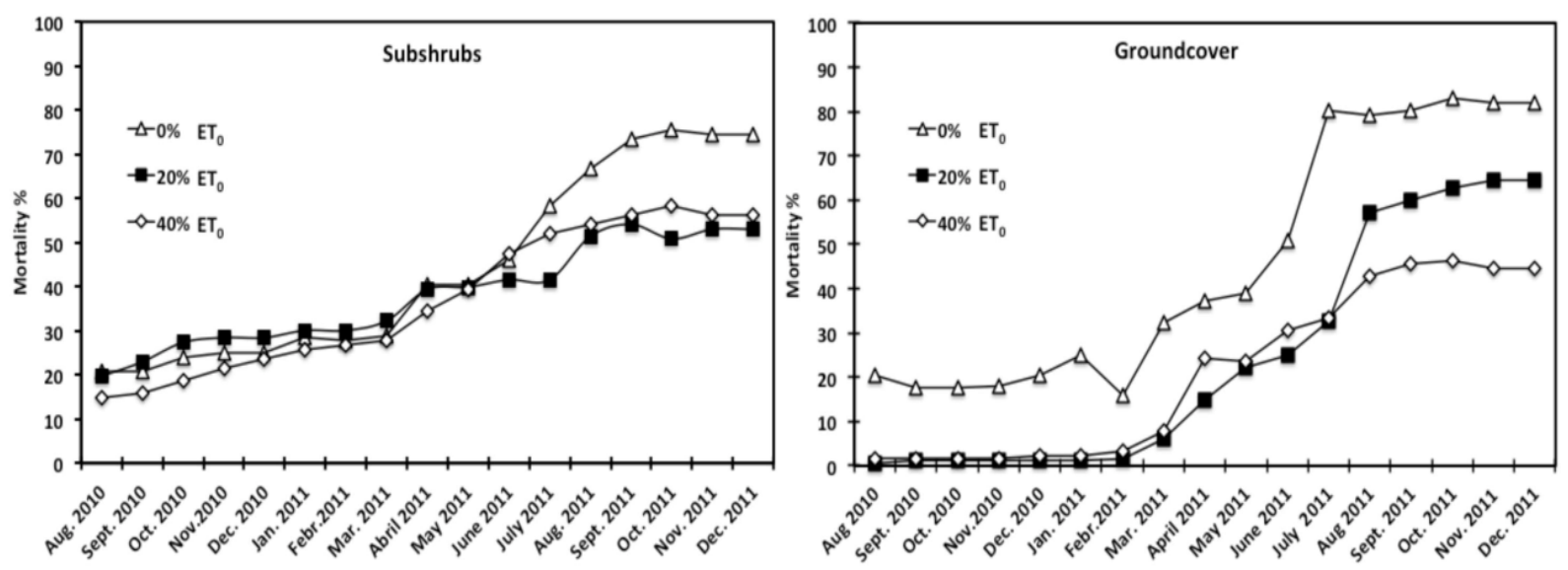

Figure 2. (2a. Subshrubs; 2b. Groundcover) Mortality percentages for the two green roofs between August 2010 and December 2011 for $0 \%, 20 \%$ and $40 \% \mathrm{ET}_{0}$ irrigation treatments

\subsection{Vegetation Cover}

In the green roof containing subshrub species, soil cover increased from April 2011 in the irrigated plots, while soil cover of the plants which received no irrigation began to fall after June 2011 (Figure 3a).

In the green roof simulation containing groundcover species, soil cover was at its highest in the summer and autumn months for the irrigated plots (Figure 3b). Non-irrigated plants in both simulations achieved a lower soil coverage. The green roof with groundcover species showed wider variations in cover than the green roof with subshrub species, particularly during winter months.
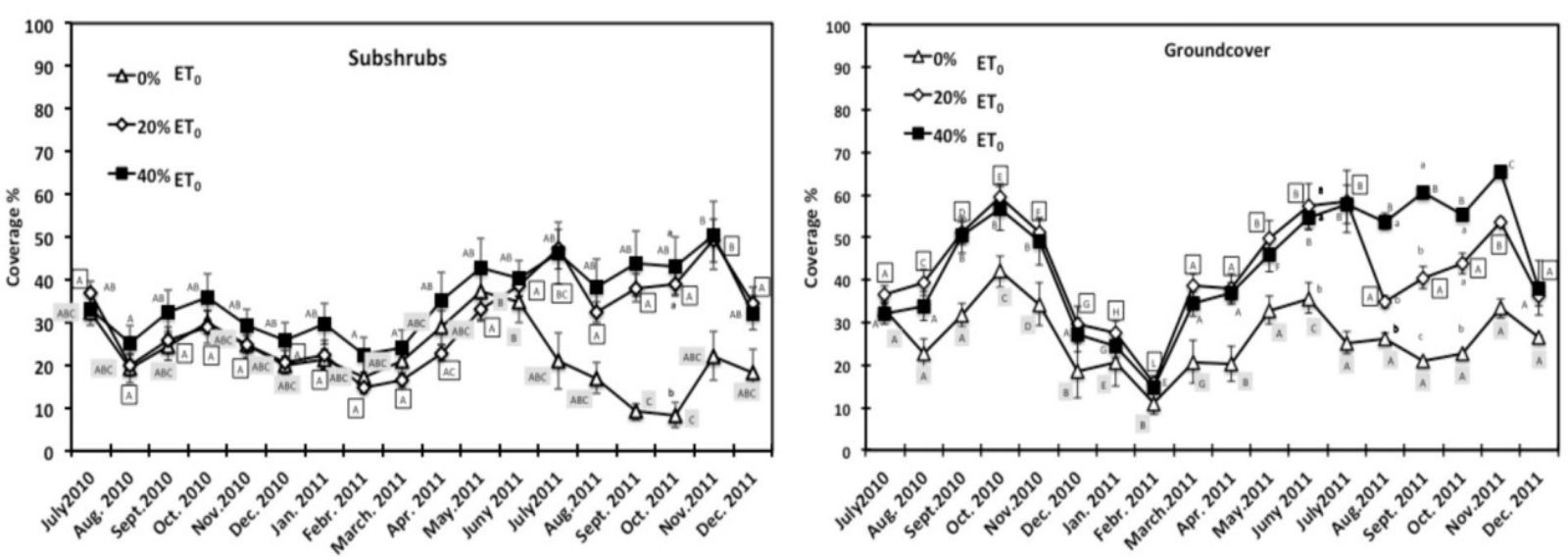

Figure 3. (3a. Subshrubs; 3b. Groundcover). Evolution of cover (percentages \pm SE) between July 2010 and December 2011 for the three irrigation treatments of $0 \%, 20 \%$ and $40 \% \mathrm{ET}_{0}$ in the two green roof simulations (groundcover and subshrubs). Different upper-case letters indicate significant differences between one data collection date and another for the same irrigation treatment. Different lower-case letters indicate significant difference between different irrigation treatments for the same data collection date (significance level $\mathrm{P}<0.05$ ) 


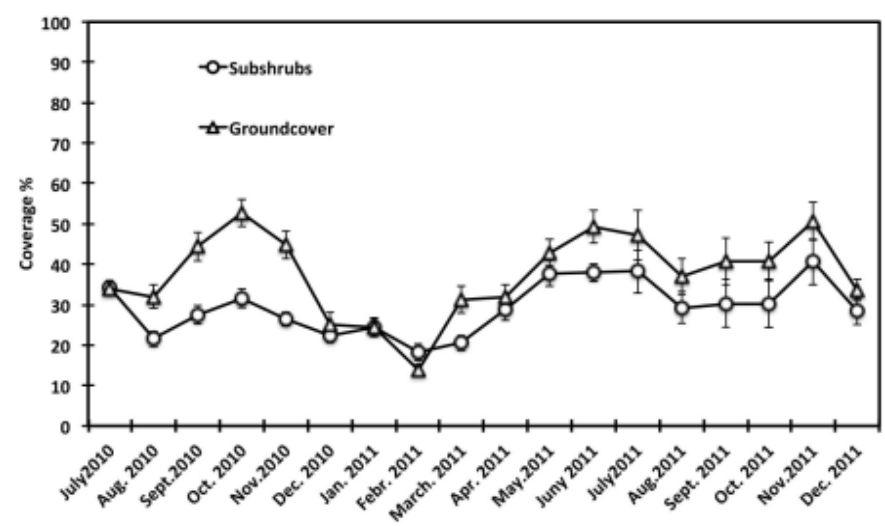

Figure 4. Evolution of cover (percentages \pm SE) between July 2010 and December 2011 for the two green roofs (groundcover and subshrubs). Each value represents an average of all three irrigation treatments $0 \%, 20 \%$ and $40 \% \mathrm{ET}_{0}$

A comparison between vegetation cover in the two green roofs, made through monthly observations of average values of all three irrigation treatments reveals higher increases for the groundcover species (Figure 4).

\subsection{Flowering}
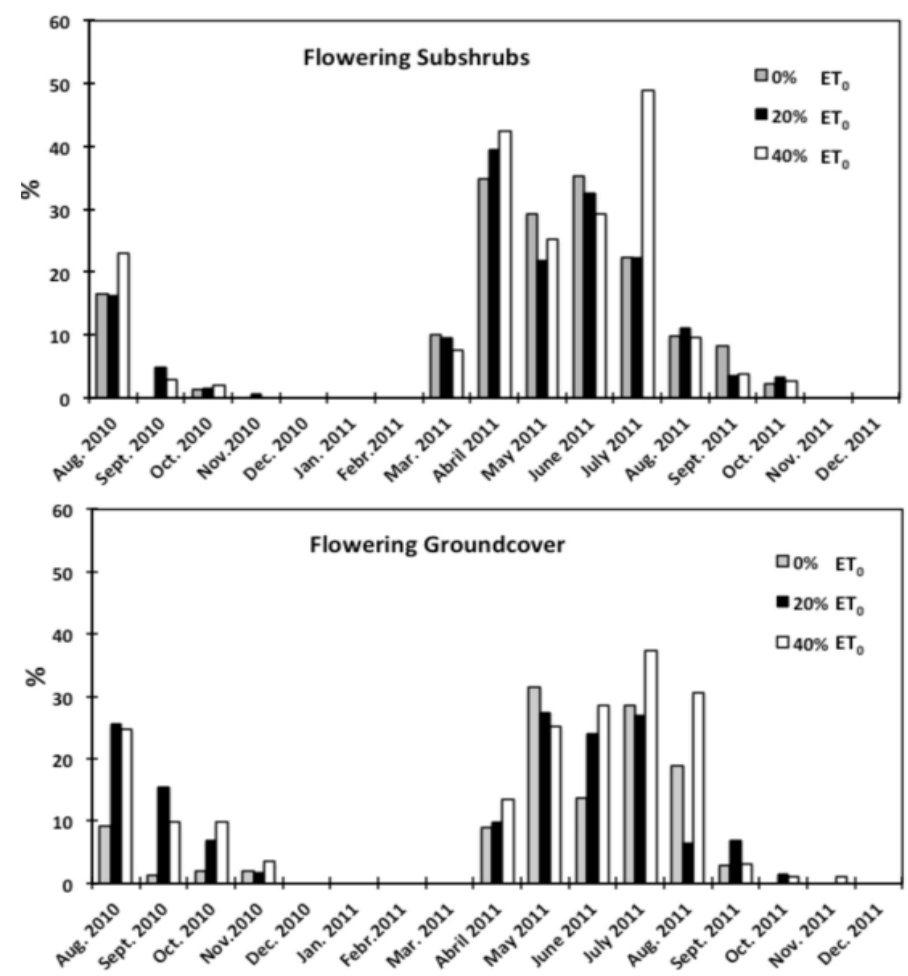

Figure 5. (above: Subshrubs below: Groundcover) Flowering rates for the three irrigation treatments $(0,20$ and $40 \% \mathrm{ET}_{0}$ ) from August 2010 to December 2011. Values were calculated monthly for the total number of living plants

Flowering in the two green roofs was more intense and prolonged in the $40 \% \mathrm{ET}_{0}$ irrigated plots, especially during the hottest period. Flowering of the groundcover species lasted until August while that of the subshrub species ended in July (Figures $5 \mathrm{a}$ and $5 \mathrm{~b}$ ).

Table 5 shows the flowering results for each species in the two simulations and total duration of flowering in months. 
Table 5. Evolution of flowering during the study period. Each value indicates the number of plants in bloom for each species and for each irrigation treatment (0,20 and 40\% $\mathrm{ET}_{0}$ ) from August 2010 to December 2011 for the two green roof simulations (Subshrubs above - Groundcover below). The column on the right shows the total number of months of flowering

\begin{tabular}{|c|c|c|c|c|c|c|c|c|c|c|c|c|c|c|c|c|c|c|c|}
\hline & & 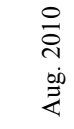 & 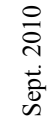 & 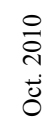 & 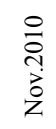 & $\begin{array}{l}\stackrel{0}{0} \\
\text { ָे } \\
\dot{0} \\
\stackrel{0}{0}\end{array}$ & 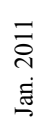 & 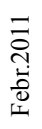 & 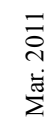 & 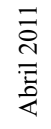 & 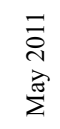 & 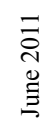 & 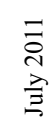 & $\begin{array}{l}\exists \\
\overline{\overbrace{}} \\
\dot{0} \\
\stackrel{\dot{\alpha}}{z}\end{array}$ & 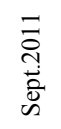 & $\begin{array}{l}\exists \\
\overline{\overbrace{}} \\
\dot{0} \\
0\end{array}$ & $\begin{array}{l}\vec{\Xi} \\
\dot{0} \\
\vec{z} \\
z\end{array}$ & $\begin{array}{l}\exists \\
\overline{\tilde{D}} \\
\dot{\delta} \\
\stackrel{0}{0}\end{array}$ & 崖 \\
\hline & & \multicolumn{18}{|c|}{ SUBSHRUBS } \\
\hline \multirow{3}{*}{$\begin{array}{l}\text { Armeria } \\
\text { maritima }\end{array}$} & $0 \% \mathrm{ET}_{0}$ & 10 & & & & & & & 6 & 14 & 6 & 1 & & & & & & & 5 \\
\hline & $20 \% \mathrm{ET}_{0}$ & 10 & & & & & & & 4 & 26 & 3 & 2 & & & & & & & 5 \\
\hline & $40 \% \mathrm{ET}_{0}$ & 18 & & & & & & & 4 & 24 & 1 & & 2 & 1 & & & & & 6 \\
\hline \multirow{3}{*}{$\begin{array}{l}\text { Asteriscus } \\
\text { maritimum }\end{array}$} & $0 \% \mathrm{ET}_{0}$ & 6 & & & & & & & & 5 & 6 & & 1 & & & & & & 4 \\
\hline & $20 \% \mathrm{ET}_{0}$ & 6 & 6 & 2 & & & & & & 7 & 5 & 4 & 3 & 3 & & & & & 8 \\
\hline & $40 \% \mathrm{ET}_{0}$ & 9 & 1 & 2 & & & & & & 7 & 7 & 4 & 2 & & 1 & & & & 8 \\
\hline \multirow{3}{*}{$\begin{array}{l}\text { Centranthus } \\
\text { ruber }\end{array}$} & $0 \% \mathrm{ET}_{0}$ & 2 & & 2 & & & & & & 9 & 9 & 5 & 4 & 6 & 2 & & & & 8 \\
\hline & $20 \% \mathrm{ET}_{0}$ & 2 & 1 & & & & & & & 6 & 11 & 4 & 6 & 7 & 3 & 2 & & & 9 \\
\hline & $40 \% \mathrm{ET}_{0}$ & 2 & 3 & 1 & & & & & & 5 & 9 & 2 & 5 & 4 & 1 & 1 & & & 10 \\
\hline \multirow{3}{*}{$\begin{array}{l}\text { Drosanthemum } \\
\text { floribundum }\end{array}$} & $0 \% \mathrm{ET}_{0}$ & & & & & & & & & & & & & & & & & & 0 \\
\hline & $20 \% \mathrm{ET}_{0}$ & & & & & & & & & 2 & & & & & & & & & 1 \\
\hline & $40 \% \mathrm{ET}_{0}$ & & & & & & & & & 1 & & & 5 & & & & & & 1 \\
\hline \multirow{4}{*}{$\begin{array}{l}\text { Helichrysum } \\
\text { stoechas }\end{array}$} & $0 \% \mathrm{ET}_{0}$ & 6 & & & & & & & & 4 & 4 & 23 & 12 & & 2 & 1 & & & 7 \\
\hline & $20 \% \mathrm{ET}_{0}$ & 6 & & & & & & & & 3 & 5 & 25 & 15 & & & 1 & & & 6 \\
\hline & $40 \% \mathrm{ET}_{0}$ & 7 & & & & & & & & 4 & 9 & 19 & 10 & 3 & 1 & 1 & & & 8 \\
\hline & $0 \% \mathrm{ET}_{0}$ & & & & & & & & 7 & & & & & & & & & & 1 \\
\hline \multirow[t]{3}{*}{ Iris lutescens } & $20 \% \mathrm{ET}_{0}$ & & & & 1 & & & & 8 & & & & & & & & & & 2 \\
\hline & $40 \% \mathrm{ET}_{0}$ & & & & & & & & 6 & & & & 4 & & & & & & 2 \\
\hline & $0 \% \mathrm{ET}_{0}$ & & & & & & & & & & & & & & & & & & 0 \\
\hline \multirow[t]{2}{*}{ Lotus creticus } & $20 \% \mathrm{ET}_{0}$ & & & & & & & & & & & & & & & & & & 0 \\
\hline & $40 \% \mathrm{ET}_{0}$ & & & & & & & & & & & & 5 & & & & & & 1 \\
\hline \multirow{3}{*}{$\begin{array}{l}\text { Santolina } \\
\text { rosmarinifolia }\end{array}$} & $0 \% \mathrm{ET}_{0}$ & & & & & & & & & 6 & 7 & 6 & & & & & & & 3 \\
\hline & $20 \% \mathrm{ET}_{0}$ & & & & & & & & & & & & & & & & & & - \\
\hline & $40 \% \mathrm{ET}_{0}$ & & & & & & & & & 10 & 2 & 3 & 10 & & & & & & 4 \\
\hline \multicolumn{20}{|c|}{ GROUNDCOVER } \\
\hline \multirow{3}{*}{$\begin{array}{l}\text { Limonium } \\
\text { virgatum }\end{array}$} & $0 \% \mathrm{ET}_{0}$ & 8 & 2 & & & & & & & & & 2 & 4 & 1 & & & & & 5 \\
\hline & $20 \% \mathrm{ET}_{0}$ & 16 & 13 & & & & & & & & & 14 & 12 & 3 & & & & & 5 \\
\hline & $40 \% \mathrm{ET}_{0}$ & 15 & 7 & 7 & & & & & & & & 10 & 17 & 11 & & & & & 6 \\
\hline \multirow{3}{*}{$\begin{array}{l}\text { Thymus } \\
\text { serpillum }\end{array}$} & $0 \% \mathrm{ET}_{0}$ & 2 & 0 & 2 & 3 & & & & & & & 4 & 3 & 4 & & & & & 6 \\
\hline & $20 \% \mathrm{ET}_{0}$ & 15 & 10 & 6 & 2 & & & & & 1 & & 7 & 17 & & 2 & & & & 8 \\
\hline & $40 \% \mathrm{ET}_{0}$ & 16 & 10 & 10 & 6 & & & & & 4 & & 15 & 18 & 14 & & & & & 8 \\
\hline \multirow{3}{*}{$\begin{array}{l}\text { Asteriscus } \\
\text { maritimus }\end{array}$} & $0 \% \mathrm{ET}_{0}$ & 3 & 0 & 1 & & & & & & 9 & 11 & 6 & 3 & 2 & 1 & & & & 8 \\
\hline & $20 \% \mathrm{ET}_{0}$ & 14 & 4 & 6 & 1 & & & & & 13 & 15 & 11 & 3 & 2 & 2 & 1 & & & 11 \\
\hline & $40 \% \mathrm{ET}_{0}$ & 12 & & & & & & & & 13 & 14 & 9 & 9 & 6 & 3 & 1 & 1 & & 9 \\
\hline \multirow{3}{*}{$\begin{array}{l}\text { Drosanthemum } \\
\text { floribundum }\end{array}$} & $0 \% \mathrm{ET}_{0}$ & & & & & & & & & 1 & & & & & & & & & 1 \\
\hline & $20 \% \mathrm{ET}_{0}$ & & & & & & & & & 1 & 1 & & & & & & & & 2 \\
\hline & $40 \% \mathrm{ET}_{0}$ & & & & & & & & & 1 & 1 & & & & & & & & 2 \\
\hline \multirow{3}{*}{$\begin{array}{l}\text { Dymondia } \\
\text { margaretae }\end{array}$} & $0 \% \mathrm{ET}_{0}$ & & & & & & & & & & & & & & & & & & - \\
\hline & $20 \% \mathrm{ET}_{0}$ & & & & & & & & & & & & & & & & & & - \\
\hline & $40 \% \mathrm{ET}_{0}$ & & & & & & & & & & & & & & & & & & - \\
\hline \multirow{3}{*}{$\begin{array}{l}\text { Frankenia } \\
\text { laevis }\end{array}$} & $0 \% \mathrm{ET}_{0}$ & & & & & & & & & & 23 & & & & & & & & 1 \\
\hline & $20 \% \mathrm{ET}_{0}$ & & & & & & & & & & 21 & & & & 1 & & & & 2 \\
\hline & $40 \% \mathrm{ET}_{0}$ & & & & & & & & & & 19 & 1 & & & & & & & 2 \\
\hline
\end{tabular}




\subsection{Biomass}

There were no significant differences in biomass between different irrigation treatments in the two simulations. Groundcover species revealed a greater biomass than that of the subshrubs (Table 6).

Table 6. Dry biomass weight values $( \pm \mathrm{SE})$ of different plant parts for each irrigation treatment $(0,20$ and $40 \%$ $\mathrm{ET}_{0}$ ). Each value is calculated for the total number of living plants. The number of living plants is shown in the first column. Average values not associated with the same letter are significantly different at $p<0.05$ (Test Tukey Kramer HSD)

\begin{tabular}{|c|c|c|c|c|c|c|c|}
\hline \multirow{2}{*}{ Irrigation } & \multirow{2}{*}{$\mathrm{N}^{\mathrm{o}}$ plants } & \multicolumn{2}{|c|}{ Aboveground (g) } & \multicolumn{2}{|c|}{ Roots (g) } & \multicolumn{2}{|c|}{ Total (g) } \\
\hline & & Total & Mean & Total & Mean & Total & Mean \\
\hline GROUNDCOVER $0 \% \mathrm{ET}_{0}$ & 14 & 1097,2 & $78,4 \pm 40,9 \mathrm{~A}$ & 331,1 & $23,6 \pm 11,7 \mathrm{~A}$ & 1428,2 & $102,0 \pm 52,2 \mathrm{~A}$ \\
\hline GROUNDCOVER $20 \% \mathrm{ET}_{0}$ & 18 & 2487,0 & $138,2 \pm 49,2 \mathrm{~A}$ & 371,5 & $20,6 \pm 5,5 \mathrm{~A}$ & 2858,5 & $158,8 \pm 53,9 \mathrm{~A}$ \\
\hline GROUNDCOVER $40 \% \mathrm{ET}_{0}$ & 32 & 2671,9 & $83,5 \pm 26,3 \mathrm{~A}$ & 748,0 & $23,4 \pm 5,7 \mathrm{~A}$ & 3419,9 & $106,9 \pm 31,5 \mathrm{~A}$ \\
\hline SUBSHRUBS $0 \% \mathrm{ET}_{0}$ & 23 & 135,7 & $5,9 \pm 1,5 \mathrm{~A}$ & 98,9 & $4,3 \pm 1,1 \mathrm{~A}$ & 234,6 & $10,2 \pm 2,2 \mathrm{~A}$ \\
\hline SUBSHRUBS $20 \% \mathrm{ET}_{0}$ & 49 & 1129,1 & $23,0 \pm 5,6 \mathrm{~A}$ & 418,2 & $8,5 \pm 1,8 \mathrm{~A}$ & 1547,3 & $31,6 \pm 6,8 \mathrm{~A}$ \\
\hline SUBSHRUBS $40 \% \mathrm{ET}_{0}$ & 43 & 1212,2 & $28,2 \pm 8,6 \mathrm{~A}$ & 229,8 & $5,3 \pm 0,9 \mathrm{~A}$ & 1442,1 & $33,5 \pm 9,4 \mathrm{~A}$ \\
\hline
\end{tabular}

\subsection{Plant Diversity}
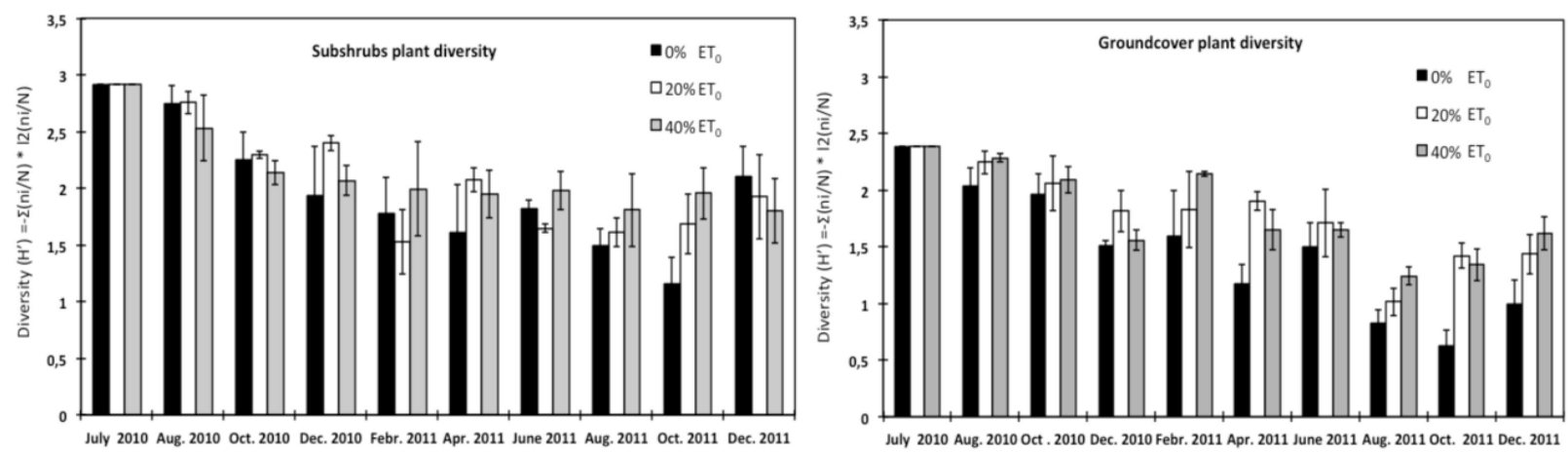

Figure 6. (6a. Subshrubs; 6b. Groundcover) Plant diversity trends calculated with the Shannon Wiener index for three irrigation treatments $\left(0,20\right.$ and $40 \%$ of $\left.\mathrm{ET}_{0}\right)$ from August 2010 to December 2011. Data was retrieved twice monthly beginning in July 2010

Figure 6 shows plant diversity trends for both green roofs calculated with the Shannon Wiener index (H') throughout the entire trial period. In both trials diversity rates fell with respect to the initial values, especially for the non-irrigated plots (with exceptions among the subshrub species).

\subsection{Species Presence}

Tables 7 and 8 show the evolution of the presence of all plant species in the two trials throughout the study period. In the subshrubs trial there was a reduction in the number of planted species for all irrigation treatments. 
Table 7. Presence rate $(\% \pm \mathrm{SE})$ of all species for three irrigation treatments $\left(0,20\right.$ and $\left.40 \% \mathrm{ET}_{0}\right)$ from August 2010 to December 2011 calculated for the subshrubs simulation green roof. The data was collected twice monthly for species planted at the beginning of the trial and for colonising species. Data was collected from July 2010

\begin{tabular}{|c|c|c|c|c|c|c|c|c|c|c|c|c|}
\hline & & & $\begin{array}{l}\text { July } \\
2010\end{array}$ & $\begin{array}{l}\text { Aug. } \\
2010\end{array}$ & $\begin{array}{l}\text { Oct. } \\
2010\end{array}$ & $\begin{array}{l}\text { Dec. } \\
2010\end{array}$ & $\begin{array}{l}\text { Febr. } \\
2011\end{array}$ & $\begin{array}{l}\text { Apr. } \\
2011\end{array}$ & $\begin{array}{l}\text { June } \\
2011\end{array}$ & $\begin{array}{l}\text { Aug. } \\
2011\end{array}$ & $\begin{array}{l}\text { Oct. } \\
2011\end{array}$ & $\begin{array}{l}\text { Dec. } \\
2011\end{array}$ \\
\hline \multirow{3}{*}{$\begin{array}{l}\text { Armeria } \\
\text { maritima }\end{array}$} & \multirow{3}{*}{ planted } & $0 \% \mathrm{ET}_{0}$ & 11,5 & $2,4 \pm 0,7$ & $0,3 \pm 0,3$ & $0,7 \pm 0,3$ & $1,0 \pm 0,6$ & $0,7 \pm 0,7$ & $0,7 \pm 0,7$ & & & \\
\hline & & $20 \% \mathrm{ET}_{0}$ & 11,5 & $3,8 \pm 2,1$ & $0,7 \pm 0,7$ & & $0,3 \pm 0,3$ & $1,0 \pm 0,6$ & & & & \\
\hline & & $40 \% \mathrm{ET}_{0}$ & 11,5 & $1,4 \pm 0,7$ & $0,7 \pm 0,3$ & $0,7 \pm 0,7$ & $1,0 \pm 0,6$ & $0,7 \pm 0,7$ & $0,3 \pm 0,3$ & & $0,3 \pm 0,3$ & $0,3 \pm 0,3$ \\
\hline \multirow{3}{*}{$\begin{array}{l}\text { Asteriscus } \\
\text { maritimus }\end{array}$} & \multirow{3}{*}{ planted } & $0 \% \mathrm{ET}_{0}$ & 5,2 & $3,1 \pm 1,2$ & $3,1 \pm 2,2$ & $2,4 \pm 1,5$ & & $1,4 \pm 1,4$ & $1,4 \pm 1,4$ & $0,3 \pm 0,3$ & & $0,3 \pm 0,3$ \\
\hline & & $20 \% \mathrm{ET}_{0}$ & 5,2 & $5,6 \pm 1,3$ & $5,2 \pm 3,7$ & $5,9 \pm 2,3$ & & $3,5 \pm 1,9$ & $2,8 \pm 2,8$ & $2,8 \pm 2,8$ & $1,4 \pm 1,4$ & $2,8 \pm 2,3$ \\
\hline & & $40 \% \mathrm{ET}_{0}$ & 5,2 & $3,8 \pm 0,9$ & $4,9 \pm 1,3$ & $3,5 \pm 0,3$ & $1,4 \pm 0,7$ & $1,4 \pm 0,3$ & $1,7 \pm 0,9$ & & $1,7 \pm 0,9$ & $0,7 \pm 0,7$ \\
\hline \multirow{3}{*}{$\begin{array}{l}\text { Centranthus } \\
\text { ruber }\end{array}$} & \multirow{3}{*}{ planted } & $0 \% \mathrm{ET}_{0}$ & 5,2 & $4,5 \pm 1,7$ & $9,0 \pm 4,9$ & $6,3 \pm 3,1$ & $1,7 \pm 0,3$ & $6,9 \pm 3,4$ & $16,7 \pm 7,4$ & $16,7 \pm 3,7$ & $7,3 \pm 3,0$ & $8,0 \pm 3,0$ \\
\hline & & $20 \% \mathrm{ET}_{0}$ & 5,2 & $4,5 \pm 0,7$ & $7,3 \pm 1,8$ & $4,5 \pm 1,9$ & $1,0 \pm 0,6$ & $9,7 \pm 3,1$ & $13,2 \pm 2,8$ & $11,1 \pm 4,0$ & $16,0 \pm 4,5$ & $12,5 \pm 5,8$ \\
\hline & & $40 \% \mathrm{ET}_{0}$ & 5,2 & $4,9 \pm 1,3$ & $5,9 \pm 3,0$ & $3,1 \pm 3,1$ & $1,0 \pm 0,6$ & $4,9 \pm 1,8$ & $4,9 \pm 1,8$ & $2,4 \pm 0,9$ & $3,5 \pm 0,7$ & $2,4 \pm 0,3$ \\
\hline \multirow{3}{*}{$\begin{array}{l}\text { Drosanthemum } \\
\text { floribundum }\end{array}$} & \multirow{3}{*}{ planted } & $0 \% \mathrm{ET}_{0}$ & 5,2 & $4,9 \pm 0,3$ & $6,6 \pm 0,9$ & $0,7 \pm 0,7$ & $4,5 \pm 1,7$ & $1,0 \pm 1,0$ & $0,3 \pm 0,3$ & & & \\
\hline & & $20 \% \mathrm{ET}_{0}$ & 5,2 & $4,5 \pm 0,7$ & $3,8 \pm 1,3$ & $1,4 \pm 0,9$ & $2,1 \pm 0,0$ & & & & & \\
\hline & & $40 \% \mathrm{ET}_{0}$ & 5,2 & $4,5 \pm 0,3$ & $2,8 \pm 1,8$ & $0,0 \pm 0,0$ & $4,5 \pm 1,5$ & & & & & \\
\hline \multirow{4}{*}{$\begin{array}{l}\text { Helichrysum } \\
\text { stoechas }\end{array}$} & \multirow{3}{*}{ planted } & $0 \% \mathrm{ET}_{0}$ & 10,4 & $2,4 \pm 0,9$ & $2,8 \pm 0,9$ & $2,8 \pm 0,9$ & $4,2 \pm 1,2$ & $7,6 \pm 3,9$ & $12,5 \pm 3,9$ & $8,0 \pm 4,6$ & $3,5 \pm 1,9$ & $2,8 \pm 0,9$ \\
\hline & & $20 \% \mathrm{ET}_{0}$ & 10,4 & $6,3 \pm 0,6$ & $5,9 \pm 1,3$ & $5,6 \pm 0,9$ & $8,3 \pm 1,0$ & $13,5 \pm 0,0$ & $18,4 \pm 0,9$ & $17,4 \pm 0,9$ & $14,2 \pm 6,8$ & $10,1 \pm 4,0$ \\
\hline & & $40 \% \mathrm{ET}_{0}$ & 10,4 & $4,2 \pm 0,6$ & $2,4 \pm 0,9$ & $4,2 \pm 0,6$ & $3,1 \pm 1,2$ & $3,8 \pm 1,5$ & $13,9 \pm 2,8$ & $15,6 \pm 2,6$ & $16,0 \pm 0,3$ & $12,2 \pm 1,9$ \\
\hline & \multirow{3}{*}{ planted } & $0 \% \mathrm{ET}_{0}$ & 10,4 & $2,8 \pm 0,3$ & $0,3 \pm 0,3$ & & $0,3 \pm 0,3$ & $1,7 \pm 0,9$ & $1,0 \pm 0,6$ & & & $1,0 \pm 0,6$ \\
\hline \multirow[t]{3}{*}{ Iris lutescens } & & $20 \% \mathrm{ET}_{0}$ & 10,4 & $1,7 \pm 1,6$ & & $2,1 \pm 2,1$ & $0,7 \pm 0,7$ & $0,7 \pm 0,7$ & $0,7 \pm 0,3$ & & $0,3 \pm 0,3$ & \\
\hline & & $40 \% \mathrm{ET}_{0}$ & 10,4 & $1,4 \pm 0,9$ & & $2,1 \pm 1,0$ & $1,0 \pm 0,6$ & $2,1 \pm 1,0$ & $0,7 \pm 0,3$ & $0,7 \pm 0,7$ & $0,3 \pm 0,3$ & $0,7 \pm 0,7$ \\
\hline & \multirow{3}{*}{ planted } & $0 \% \mathrm{ET}_{0}$ & 5,2 & $3,8 \pm 0,7$ & $4,9 \pm 1,5$ & $5,9 \pm 2,4$ & & & $0,3 \pm 0,3$ & & & \\
\hline \multirow[t]{3}{*}{ Lotus creticus } & & $20 \% \mathrm{ET}_{0}$ & 5,2 & $5,2 \pm 0,6$ & $9,4 \pm 1,6$ & $3,5 \pm 0,3$ & & & & & & \\
\hline & & $40 \% \mathrm{ET}_{0}$ & 5,2 & $5,6 \pm 0,3$ & $10,1 \pm 1,3$ & $9,0 \pm 3,1$ & & $6,9 \pm 6,9$ & & & & \\
\hline & \multirow{3}{*}{ planted } & $0 \% \mathrm{ET}_{0}$ & 10,4 & $7,6 \pm 4,0$ & $10,4 \pm 6,3$ & $8,3 \pm 5,9$ & $9,4 \pm 7,4$ & $13,5 \pm 9,7$ & $8,3 \pm 8,3$ & $2,4 \pm 2,4$ & & \\
\hline \multirow[t]{3}{*}{$\begin{array}{l}\text { Santolina } \\
\text { rosmarinifolia }\end{array}$} & & $20 \% \mathrm{ET}_{0}$ & 10,4 & $6,6 \pm 3,5$ & $1,4 \pm 1,4$ & $1,7 \pm 1,3$ & $0,7 \pm 0,7$ & $0,7 \pm 0,7$ & & & & \\
\hline & & $40 \% \mathrm{ET}_{0}$ & 10,4 & $14,9 \pm 6,1$ & $18,1 \pm 7,3$ & $15,6 \pm 5,9$ & $13,9 \pm 5,3$ & $17,7 \pm 3,7$ & $11,8 \pm 11,8$ & $5,6 \pm 5,6$ & & \\
\hline & & $0 \% \mathrm{ET}_{0}$ & & & & & & & & $0,3 \pm 0,3$ & & \\
\hline \multirow[t]{3}{*}{$\begin{array}{l}\text { Conyza } \\
\text { bonariensis }\end{array}$} & colonizing & $20 \% \mathrm{ET}_{0}$ & & & & & & $0,3 \pm 0,3$ & $0,7 \pm 0,7$ & $0,3 \pm 0,3$ & $2,1 \pm 1,0$ & $1,7 \pm 1,3$ \\
\hline & & $40 \% \mathrm{ET}_{0}$ & & & & & & & $1,0 \pm 0,6$ & $5,9 \pm 2,8$ & $10,8 \pm 2,7$ & $4,5 \pm 2,3$ \\
\hline & & $0 \% \mathrm{ET}_{0}$ & & & & & & & & & $0,3 \pm 0,3$ & $0,5 \pm 0,5$ \\
\hline \multirow[t]{3}{*}{$\begin{array}{l}\text { Frankenia } \\
\text { laevis }\end{array}$} & colonizing & $20 \% \mathrm{ET}_{0}$ & & & & & & & & & $0,3 \pm 0,3$ & $0,3 \pm 0,3$ \\
\hline & & $40 \% \mathrm{ET}_{0}$ & & & & & & & & & & $0,3 \pm 0,3$ \\
\hline & & $0 \% \mathrm{ET}_{0}$ & & & & & & & & $0,3 \pm 0,3$ & $0,7 \pm 0,7$ & \\
\hline \multirow[t]{3}{*}{ Gramínies spp } & colonizing & $20 \% \mathrm{ET}_{0}$ & & & & & & & & & & \\
\hline & & $40 \% \mathrm{ET}_{0}$ & & & & & & & & & & \\
\hline & & $0 \% \mathrm{ET}_{0}$ & & & & & & & & & & $5,2 \pm 3,0$ \\
\hline \multirow[t]{2}{*}{$\begin{array}{l}\text { Lactuca } \\
\text { perennis }\end{array}$} & colonizing & $20 \% \mathrm{ET}_{0}$ & & & & & & & & & & \\
\hline & & $40 \% \mathrm{ET}_{0}$ & & & & & & & & & & \\
\hline
\end{tabular}




\begin{tabular}{|c|c|c|c|c|c|c|c|c|c|c|}
\hline \multirow{3}{*}{$\begin{array}{l}\text { Oxalys } \\
\text { corniculata }\end{array}$} & \multirow{3}{*}{ colonizing } & $0 \% \mathrm{ET}_{0}$ & & & & & & & & $1,0 \pm 1,0$ \\
\hline & & $20 \% \mathrm{ET}_{0}$ & & & & & & & & \multirow[t]{2}{*}{$2,4 \pm 1,3$} \\
\hline & & $40 \% \mathrm{ET}_{0}$ & & & & & & & & \\
\hline \multirow{3}{*}{$\begin{array}{l}\text { Sonchus } \\
\text { oleraceus }\end{array}$} & \multirow{3}{*}{ colonizing } & $0 \% \mathrm{ET}_{0}$ & $0,3 \pm 0,3$ & $0,3 \pm 0,3$ & & $0,3 \pm 0,3$ & $1,7 \pm 1,7$ & & & $3,5 \pm 2,1$ \\
\hline & & $20 \% \mathrm{ET}_{0}$ & & $1,4 \pm 1,4$ & $0,3 \pm 0,3$ & $2,1 \pm 1,0$ & & & & \\
\hline & & $40 \% \mathrm{ET}_{0}$ & & $0,3 \pm 0,3$ & & & $2,3 \pm 0,8$ & $1,0 \pm 1,0$ & $1,7 \pm 1,7$ & $2,1 \pm 2,1$ \\
\hline \multirow{3}{*}{$\begin{array}{l}\text { Thymus } \\
\text { serpyllum }\end{array}$} & \multirow{3}{*}{ colonizing } & $0 \% \mathrm{ET}_{0}$ & & & & $0,7 \pm 0,7$ & $3,1 \pm 1,2$ & $1,7 \pm 0,9$ & & $0,5 \pm 0,5$ \\
\hline & & $20 \% \mathrm{ET}_{0}$ & & & & $2,1 \pm 1,2$ & $9,0 \pm 5,8$ & $14,6 \pm 6,8$ & $20, \pm 10,7$ & $17, \pm 10,1$ \\
\hline & & $40 \% \mathrm{ET}_{0}$ & & & $0,3 \pm 0,3$ & $4,9 \pm 4,4$ & $12,8 \pm 6,7$ & $23,6 \pm 10,2$ & $29,2 \pm 10,7$ & $25, \pm 14,2$ \\
\hline
\end{tabular}

At the end of the trial the species with highest survival rates were Centranthus ruber and Helichrysum stoechas along with small quantities of other surviving species, mostly in the $40 \% \mathrm{ET}_{0}$ plot.

In the non-irrigated portions of the groundcover green roof the reduction of species became more severe from June 2011. The surviving species at the end of the trial were Frankenia laevis, Asteriscus maritimus and Thymus serpyllum.

Among the irrigated plants the highest presence values were achieved by Thymus serpyllum and Frankenia laevis and to a lesser degree by Asteriscus maritimus. A minimal presence of other species was also observed. Plant presence values were higher in the $40 \% \mathrm{ET}_{0}$ irrigated plots.

Colonising plants in the subshrubs green roof saw an increased presence from April 2011. Throughout the study period seven species were counted in the non-irrigated subplots. Five species were counted in the $20 \% \mathrm{ET}_{0}$ plots and 4 in the $40 \%$ plots. Thymus serpyllum was the species which reached the highest level of presence in the $20 \%$ and $40 \% \mathrm{ET}_{0}$ plots. The abundance of this species could be due to transfer from the nearby groundcover green roof.

The presence of colonising species in the groundcover green roof was minimal both in terms of number of species and in terms of presence: three species were observed in the non irrigated plots and in the $40 \% \mathrm{ET}_{0}$ plots, and two species were observed in the $20 \% \mathrm{ET}_{0}$ plots.

Table 8. Presence rate $(\% \pm \mathrm{SE})$ of all species for three irrigation treatments $\left(0,20\right.$ and $40 \%$ of $\left.\mathrm{ET}_{0}\right)$ from August 2010 to December 2011 calculated for the groundcover simulation green roof. The data was collected twice monthly for species planted at the beginning of the trial and for colonising species. Data was collected from July 2010

\begin{tabular}{|c|c|c|c|c|c|c|c|c|c|c|c|c|}
\hline & & & $\begin{array}{l}\text { July } \\
2010\end{array}$ & $\begin{array}{l}\text { Aug. } \\
2010\end{array}$ & $\begin{array}{l}\text { Oct. } \\
2010\end{array}$ & $\begin{array}{l}\text { Dec. } \\
2010\end{array}$ & $\begin{array}{l}\text { Febr. } \\
2011\end{array}$ & $\begin{array}{l}\text { Apr. } \\
2011\end{array}$ & $\begin{array}{l}\text { June } \\
2011\end{array}$ & $\begin{array}{l}\text { Aug. } \\
2011\end{array}$ & $\begin{array}{l}\text { Oct. } \\
2011\end{array}$ & $\begin{array}{l}\text { Dec. } \\
2011\end{array}$ \\
\hline \multirow{3}{*}{$\begin{array}{l}\text { Asteriscus } \\
\text { maritimus }\end{array}$} & \multirow{3}{*}{ planted } & $0 \% \mathrm{ET}_{0}$ & 6,3 & $3,8 \pm 0,7$ & $4,2 \pm 0,6$ & $3,5 \pm 0,3$ & $0,3 \pm 0,3$ & $2,8 \pm 1,5$ & $2,8 \pm 1,5$ & $1,0 \pm 0,6$ & $0,7 \pm 0,3$ & $1,0 \pm 1,0$ \\
\hline & & $20 \% \mathrm{ET}_{0}$ & 6,3 & $6,3 \pm 0,0$ & $10,8 \pm 0,3$ & $6,6 \pm 0,3$ & $1,4 \pm 0,9$ & $3,5 \pm 1,3$ & $3,1 \pm 2,2$ & $1,0 \pm 1,0$ & $3,1 \pm 1,6$ & $2,4 \pm 0,9$ \\
\hline & & $40 \% \mathrm{ET}_{0}$ & 6,3 & $4,9 \pm 1,5$ & $6,9 \pm 2,3$ & $6,3 \pm 1,0$ & & $4,5 \pm 1,5$ & $5,6 \pm 0,9$ & $6,3 \pm 1,8$ & $6,3 \pm 2,2$ & $4,9 \pm 1,4$ \\
\hline \multirow{3}{*}{$\begin{array}{l}\text { Drosanthemum } \\
\text { floribundum }\end{array}$} & \multirow{3}{*}{ planted } & $0 \% \mathrm{ET}_{0}$ & 6,3 & $5,2 \pm 1,0$ & $9,7 \pm 0,3$ & $8,7 \pm 8,7$ & $3,8 \pm 2,3$ & $0,3 \pm 0,3$ & $2,4 \pm 2,4$ & & & \\
\hline & & $20 \% \mathrm{ET}_{0}$ & 6,3 & $3,1 \pm 1,2$ & $3,8 \pm 2,3$ & $0,3 \pm 0,3$ & $1,4 \pm 1,4$ & $4,2 \pm 3,1$ & $0,3 \pm 0,3$ & & & \\
\hline & & $40 \% \mathrm{ET}_{0}$ & 6,3 & $5,6 \pm 0,3$ & $4,9 \pm 1,3$ & & $3,8 \pm 0,7$ & $1,0 \pm 1,0$ & & & & \\
\hline \multirow{3}{*}{$\begin{array}{l}\text { Dymondia } \\
\text { margaretae }\end{array}$} & \multirow{3}{*}{ planted } & $0 \% \mathrm{ET}_{0}$ & 18,8 & $8,3 \pm 1,6$ & $4,2 \pm 1,0$ & $1,7 \pm 1,3$ & $3,1 \pm 3,1$ & & & $0,3 \pm 0,3$ & & \\
\hline & & $20 \% \mathrm{ET}_{0}$ & 18,8 & $9,4 \pm 0,6$ & $5,9 \pm 2,5$ & $4,2 \pm 2,8$ & $4,9 \pm 2,7$ & $1,7 \pm 0,9$ & $0,3 \pm 0,3$ & & & \\
\hline & & $40 \% \mathrm{ET}_{0}$ & 18,8 & $10,1 \pm 1,4$ & $5,6 \pm 1,5$ & $0,7 \pm 0,7$ & $6,3 \pm 0,6$ & $1,7 \pm 0,9$ & $1,0 \pm 1,0$ & $0,3 \pm 0,3$ & & $0,3 \pm 0,3$ \\
\hline \multirow{3}{*}{$\begin{array}{l}\text { Frankenia } \\
\text { laevis }\end{array}$} & \multirow{3}{*}{ planted } & $0 \% \mathrm{ET}_{0}$ & 17,7 & $20,8 \pm 3,1$ & $26,4 \pm 4,6$ & $24,0 \pm 3,0$ & $6,9 \pm 4,4$ & $32,6 \pm 7,2$ & $24,7 \pm 1,8$ & $23,3 \pm 0,9$ & $19,1 \pm 1,5$ & $22,9 \pm 1,6$ \\
\hline & & $20 \% \mathrm{ET}_{0}$ & 17,7 & $22,9 \pm 2,4$ & $28,8 \pm 5,9$ & $30,9 \pm 2,1$ & $5,9 \pm 2,5$ & $29,5 \pm 0,7$ & $27,1 \pm 5,9$ & $17,0 \pm 5,9$ & $22,9 \pm 5,3$ & $21,2 \pm 4,8$ \\
\hline & & $40 \% \mathrm{ET}_{0}$ & 17,7 & $22,2 \pm 3,9$ & $27,4 \pm 5,1$ & $33,3 \pm 7,1$ & $6,3 \pm 2,4$ & $31,6 \pm 6,4$ & $21,2 \pm 2,5$ & $19,4 \pm 8,2$ & $21,2 \pm 7,5$ & $19,4 \pm 6,1$ \\
\hline
\end{tabular}




\begin{tabular}{|c|c|c|c|c|c|c|c|c|c|c|c|c|}
\hline & & $0 \% \mathrm{ET}_{0}$ & 6,3 & $0,7 \pm 0,7$ & $1,0 \pm 0,6$ & $1,4 \pm 0,7$ & $1,0 \pm 0,6$ & $1,4 \pm 0,9$ & $0,7 \pm 0,3$ & $0,3 \pm 0,3$ & & $0,3 \pm 0,3$ \\
\hline \multirow{3}{*}{$\begin{array}{l}\text { Limonium } \\
\text { virgatum }\end{array}$} & planted & $20 \% \mathrm{ET}_{0}$ & 6,3 & $4,2 \pm 1,6$ & $2,1 \pm 1,2$ & $4,2 \pm 2,2$ & $2,4 \pm 0,9$ & $4,9 \pm 1,5$ & $4,5 \pm 1,9$ & & & $0,7 \pm 0,7$ \\
\hline & & $40 \% \mathrm{ET}_{0}$ & 6,3 & $3,1 \pm 1,8$ & $2,8 \pm 0,3$ & $2,8 \pm 0,9$ & $3,8 \pm 0,3$ & $2,8 \pm 0,7$ & $5,6 \pm 0,9$ & & $0,3 \pm 0,3$ & $2,1 \pm 0,6$ \\
\hline & & $0 \% \mathrm{ET}_{0}$ & 6,3 & $5,6 \pm 1,5$ & $5,2 \pm 0,6$ & $4,2 \pm 2,2$ & $3,8 \pm 1,5$ & $8,3 \pm 1,6$ & $16,3 \pm 2,8$ & $1,7 \pm 0,9$ & & $0,3 \pm 0,3$ \\
\hline \multirow{3}{*}{$\begin{array}{l}\text { Thymus } \\
\text { serpyllum }\end{array}$} & planted & $20 \% \mathrm{ET}_{0}$ & 6,3 & $12,2 \pm 0,9$ & $16,3 \pm 1,3$ & $16,3 \pm 1,9$ & $10,8 \pm 1,8$ & $22,6 \pm 3,3$ & $26,7 \pm 6,1$ & $8,7 \pm 3,7$ & $21,5 \pm 6,2$ & $19,8 \pm 6,9$ \\
\hline & & $40 \% \mathrm{ET}_{0}$ & 6,3 & $14,6 \pm 1,8$ & $19,4 \pm 3,3$ & $15,3 \pm 3,6$ & $12,2 \pm 1,3$ & $24,3 \pm 0,9$ & $36,1 \pm 2,1$ & $34,0 \pm 4,9$ & $35,1 \pm 6,0$ & $28,5 \pm 3,9$ \\
\hline & & $0 \% \mathrm{ET}_{0}$ & & & & & & & $0,3 \pm 0,3$ & $0,3 \pm 0,3$ & $1,0 \pm 1,0$ & \\
\hline \multirow{3}{*}{$\begin{array}{l}\text { Conyza } \\
\text { bonariensis }\end{array}$} & colonizing & $20 \% \mathrm{ET}_{0}$ & & & & & & & $2,8 \pm 1,5$ & $0,7 \pm 0,7$ & $2,4 \pm 1,3$ & $1,0 \pm 0,6$ \\
\hline & & $40 \% \mathrm{ET}_{0}$ & & & & & & & & $1,0 \pm 0,6$ & & $0,3 \pm 0,3$ \\
\hline & & $0 \% \mathrm{ET}_{0}$ & & & & & & & & & & $2,8 \pm 1,3$ \\
\hline \multirow{3}{*}{ Lactuca } & colonizing & $20 \% \mathrm{ET}_{0}$ & & & & & & & & & & \\
\hline & & $40 \% \mathrm{ET}_{0}$ & & & & & & & & & & \\
\hline & & $0 \% \mathrm{ET}_{0}$ & & & & & & & $0,3 \pm 0,3$ & $0,7 \pm 0,7$ & $1,0 \pm 1,0$ & $1,0 \pm 0,7$ \\
\hline \multirow{2}{*}{$\begin{array}{l}\text { Sonchus } \\
\text { oleraceus }\end{array}$} & colonizing & $20 \% \mathrm{ET}_{0}$ & & & $0,3 \pm 0,3$ & & & $0,7 \pm 0,3$ & $0,3 \pm 0,3$ & $0,3 \pm 0,3$ & $0,7 \pm 0,7$ & $1,0 \pm 0,6$ \\
\hline & & $40 \% \mathrm{ET}_{0}$ & & & & $0,3 \pm 0,3$ & & & & & $1,0 \pm 0,6$ & $1,4 \pm 0,3$ \\
\hline $\begin{array}{l}\text { Santolina } \\
\text { chamaecyparissus }\end{array}$ & colonizing & $40 \% \mathrm{ET}_{0}$ & & & & & & $0,7 \pm 0,7$ & $1,0 \pm 1,0$ & & & \\
\hline
\end{tabular}

\section{Discussion}

The green roof containing groundcover species obtained a higher level of cover that the green roof with subshrub species, a situation which can be explained by structural differences between the two species groups: the subshrubs tend to develop more in terms of volume while the groundcover species grow horizontally and superficially. In the field of green roofs research, differences in biomass and foliage have been shown to have an influence on coverage, but they are also very important with regard to the improvement of the thermic and hydrological performance of a roof. Detailed in-depth studies have revealed that plants with different structures achieved different results with regard to thermic isolation and rainwater retention (Del Barrio, 1998; Jim, 2011; Nagase \& Dunnett, 2012). For both green roofs irrigation was seen to have an influence on vegetation cover. The irrigated plants predictably achieved a higher degree of cover than those which were not irrigated. Higher levels of cover depended more on the number of surviving plants than on the development of individual plants, although only the groundcover species displayed significant differences in mortality between irrigated and non-irrigated plants. Biomass figures confirmed previous data, with higher values for the groundcover green roof and for the irrigated plants, with no significant differences in average values between the two irrigation treatments $\left(20\right.$ and $\left.40 \% \mathrm{ET}_{0}\right)$. This suggests that the minimum amount of irrigation to provide could be somewhere between the evotranspiration percentages of the two irrigation treatments, an observation which could help to estimate the amount of water consumed by a green roof in a Mediterranean environment. All the same, our study recommends maintaining a minimum level of irrigation in order to achieve the levels of vegetation cover required by green roofs standards (FLL, 2008).

Another important element is the reduction in planted species that took place from June 2011. The subshrub species which survived after June 2011 were two suffruticose chamaephytes species: Centranthus ruber, Helichrysum stoechas, whereas the surviving groundcover species were reptant chamaephyte species: Frankenia laevis and Thymus serpyllum. The Raunkiær life-forms system, which classifies species according to the different bud placements, can be used to select mediterranean plant species appropriate for green roofs according to their principle characteristics (Caneva et al., 2013; Van Mechelen et al., 2014). This result is compatible with the general criteria proposed by Schulze et al. (2005), which cites suffruticose chamaephytes as being among the plants that display reduced transpiration. Generally, we have seen that the species which survived in our trial also performed well in numerous other studies on green roofs in a mediterranean environment.

Centranthus ruber has achieved optimal growth and cover in southern Tuscany (Benvenuti \& Bacci, 2010). Good performance has been observed in Greece for two species of Helicrhysum independently of substrate depth or irrigation (Papafotiou et al., 2013). Thymus serpyllum reached $85 \%$ cover a few months after planting in a 
Mediterranean environment with an $8 \mathrm{~cm}$ deep substrate (Provenzano et al., 2010).

Helichrysum stoechas and Thymus serpyllum were cited as being appropriate species for Mediterranean green roofs in a study by Caneva et al. (2013).

The species that thrived in the final part of our groundcover trial did, however, display varied performances in cover and were influenced to a greater extent by seasonal stresses during the Mediterranean summers and winters. If, therefore, we wish to make a long-term plan for a green roof we should be mindful of the variability described above and the reduction in species which was observed, as well as being aware that the eighteen months of this study cannot be considered sufficient. On this subject, Rowe et al. (2012) conducted a study lasting seven years of 25 Crassulaceae species cultivated on a green roof in Michigan, and concluded that the long-term survival of stress-tolerant species often depends on the depth of the soil; plants which initially survive can later experience a reduced cover or completely disappear due to competition, climate variations, and other causes.

The importance of flowering is not only due to its aesthetic appeal, but also to the fact that it attracts insects. Our study provides precise indications on how to achieve prolonged flowering in certain species in conditions of minimal or no irrigation. Brennesein (2005) showed that a vegetation composed of Sedum attracted only half the number of bees that were attracted by green roofs cultivated with multiple forms of vegetation, due to a shorter flowering period which made it less useful as a provider of food. In a study by Benvenuti and Bacci (2010), eighteen of the twenty species studied in a mediterranean environment flower principally in June, and half of these species also flowered briefly in autumn.

Flowering is one of the elements that defines diversity in a green roof. Biodiversity in green roofs can, apart from flowering, be determined by the way the plants respond to heterogeneous microhabitats resulting from the site-specific microclimate (Timberlake et al., 2013).

In our study, irrigation did not seem to have any particular influence on vegetation diversity, while a larger difference was observed when comparing different life forms (groundcover and subshrubs). If we compare the development of vegetation diversity, results from the Shannon Wiener index are higher for the subshrub species than for the groundcover species. Most diversity was due to the subshrub species' slightly more complex structure and to the higher presence of colonizing species. This is facilitated by the lower surface cover rate of subshrub species which favoured germination and survival of colonising species. In the subshrubs trial a higher presence of colonising species was observed, and this did not seem to change in response to different irrigation treatments, whereas abundance did vary according to the amount of water received. Many colonising species did not achieve a sufficient presence to be judged for their aesthetic or functional characteristics, and the results tell us that it is not always possible to rely on spontaneous colonisation of green roofs to increase cover and biodiversity.

The reduction of species in the green roofs over time and the danger of seeing the development of low diversity with a small number of dominant species has already been observed (Dunnett et al., 2008; Nagase \& Dunnett, 2010). For this reason it is important to include green roofs in a network of urban ecological connectivity, and organise a plan of agronomic management with removal and substitution of species, and the preparation of microhabitats on green roofs (Köhler, 2006).

\section{Conclusions}

The results of this study suggest that green roofs in the Mediterranean area are viable, although longer study periods will be necessary in order to better understand how the vegetation we have used behaves over time. Our initial findings proved that there are species which can be used in that they achieve good results in the difficult environment of Mediterranean green roofs. Different irrigation treatments resulted in differences between irrigated plants and non irrigated plants, demonstrating that a minimum level of irrigation is necessary. Both trials saw a simplification of the initial design due to a reduction in species and an increase in the abundance of the surviving species. Structural differences between the vegetation of the two trials influenced the results of the study principally in terms of diversity and the ability to host colonising species. The level of colonisation in the groundcover trial was lower than that in the subshrub trial. Aesthetic considerations which took into account parameters of cover and flowering revealed good flowering rates in those species which were present. Variations in cover were observed especially with regard to the groundcover plants, which were more affected by the seasonal stresses typical of the Mediterranean climate.

The main risk could be that of having a green roof with a small number of species and minimal diversity in vegetation and aesthetic characteristics. This problem can be overcome with a small amount of maintenance by 
replacing some species over time.

The two trials and their different irrigation treatments have, throughout the duration of the study, shown a reduction in the number of species and, consequently, a reduction in flowering and diversity performance.

\section{Acknowledgements}

We would like to thank the Spanish government for their economic contributions received through the MINECO, IMPACTO, and CUMED projects.

We are also grateful for the technical support given in the field and the laboratory by Marc Ferrer, Laia Serra, Cristian Morales, Beatriz Grau, and Inma Funes, of the IRTA.

\section{References}

Àrea de Medi Ambient, Ajuntament de Barcelona. (2010). Els corredors verds urbans. Exemples $i$ criteris de disseny. In Catalan. Retrieved July 21, 2013, from http://www.ajsosteniblebcn.cat/corredors-verds-urbans 31473.pdf

Àrea de Medi Ambient, Ajuntament de Barcelona. (2011). Cobertes i Murs Verds a Barcelona. Estudi sobre les existentes, el potencial i les estratègies d'implantació. In Catalan. Retrieved July 10, 2013, from $\mathrm{http} / / / \mathrm{bcnecologia} . n e t /$ sites/default/files/proyectos/doc_cobertes_i_murs_verds_01m2010_0.pdf

Bass, B. (2009). Biodiversity Research Protocol. Proceedings of workshop: Green Roofs for Healthy Cities Draft Biodiversity Research Protocol. Retrieved November 10, 2011, from http://www.greenroofs.org/resources/Biodiversity_Research_on_Green_Roofs_Protocol_2009.pdf

Bates, A. J., Sadler, J. P., \& Mackay, R. (2013). Vegetation development over four years on two green roofs in the UK. Urban For. Urban Green, 12, 98-108. http://dx.doi.org/10.1016/j.ufug.2012.12.003

Benvenuti, S., \& Bacci, D. (2010). Initial agronomic performances of Mediterranean xerophytes in simulated dry green roofs. Urban Ecosyst, 13, 349-363. http://dx.doi.org/10.1007/s11252-010-0124-9

Benvenuti, S. (2014). Wildflower green roofs for urban landscaping, ecological sustainability and biodiversity. Landscape Urban Plan, 124, 151-161. http://dx.doi.org/10.1016/j.landurbplan.2014.01.004

Brennesein, S. (2005). The Natural Roof (Project NADA). Proceedings of Research Project Report on the Use of Extensive Green Roofs by Wild Bees. Hochschule University of Wädenswil, November 2005.

Caneva, G., Kumbaric, A., Savo, V., \& Casalini, R. (2013). Ecological approach in selecting extensive green roof plants: A data-set of Mediterranean plants. Plant Biosystems, 2, 374-383. http://dx.doi:org/10.1080/11263504.2013.819819

Carter, T., \& Butler, C. (2008). Ecological impacts of replacing traditional roofs with green roofs in two urban areas. Cities and the Environment, 1, 1-17.

Casadesús, J., Biel, C., \& Savé, R. (2005). Turf color measurement with conventional digital cameras. Proceedings of EFITA/WCCA Joint Congress On It In Agriculture, July 25-28, 2005, Vila Real, Portugal.

Casadesús, J., Kaya, Y., Bort, J., Nachit, M. M., Araus, J. L., Amor, S., ... Villegas, D. (2007). Water Use Efficiency. Using vegetation indices derived from conventional digital cameras as selection criteria for wheat breeding in water-limited environments. Ann. Appl. Biol., 150, 227-236. http://dx.doi.org/10.1111/j.1744-7348.2007.00116.x

Del Barrio, E. P. (1998). Analysis of the green roofs cooling potential in buildings. Energ. Buildings, 27, 179-193. http://dx.doi.org/10.1016/s0378-7788(97)00029-7

Dunnett, N., \& Nolan, A. (2004). The Effect of Substrate Depth and Supplementary Watering on the Growth of Nine Herbaceous Perennials in a Semi-extensive Green Roof. In R. Junge-Berberovic et al. (Eds.), Acta Hort 643. Proceedings of IC on Urban Horticulture. ISHS 2004. http://dx.doi.org/10.17660/actahortic.2004.643.40

Dunnett, N., Nagase, A., \& Hallam, A. (2008). The dynamics of planted and colonising specieson a green roof over six growing seasons 2001-2006: Influence of substrate depth. Urban Ecosyst, 11, 373-384. http://dx.doi.org/10.1007/s11252-007-0042-7

Ekşi, M., \& Uzun, A. (2013). Investigation of thermal benefits of an extensive green roof in Istanbul climate. Scientific Research and Essays. http://dx.doi.org/10.5897/SRE12.713

FLL, German Landscape Research, Development and Construction Society. (2008). Guidelines for the Planning, 
Construction and Maintenance of Green Roofing. Bonn, Germany.

Getter, K. L., \& Rowe, D. B. (2009). Substrate Depth Influences Sedum Plant Community on a Green Roof. Hortscience, 44(2), 401-407.

Greater London Authority. (2008). Living Roofs and Walls Technical Report: Supporting London Plan Policy. Published by: City Hall, The Queen's Walk London SE1 2AA. Retrieved from http://www.london.gov.uk

IPCC. (2013). Climate Change. Five Assessment Report. Retrieved from http://www.ipcc.ch/publications_and_data/publications_and_data_reports.shtml-1

Jim, C. Y. (2011). Effect of vegetation biomass structure on thermal performance of tropical green roof. Landscape Ecol Eng., 8, 173-187. http://dx.doi.org/10.1007/s11355-011-0161-4

Köhler, M. (2006). Long-Term Vegetation Research on Two Extensive Green Roofs in Berlin. Urban Habitats, 4 , 3-26. Retrieved from http://urbanhabitats.org

Liu, K., \& Baskaran, B. (2003). Thermal Performance of Green Roofs Through Field Evaluation. Proceedings of First North American Green Roof Infrastructure Conference, Awards and Trade Show. Chicago, IL. May 29-30, 2003.

Liu, K., \& Minor, J. (2005). Performance evaluation of an extensive green roof. Proceedings of 3rd North American Green Roof Conference: Greening rooftops for Sustainable communities (pp. 1-11). Washington, DC. May 5-6, 2005.

Lundholm, J. T. (2006). Green roofs and facades: A habitat template approach. Urban Habitats, 4, 87-101. Retrieved from http://www.urbanhabitats.org

Mentens, J., Raes, D., \& Hermy, M. (2006). Green roofs as a tool for solving the rainwater runoff problem in the urbanized 21st century? Landscape Urban Plan., $217-226$. http://dx.doi.org/10.1016/j.landurbplan.2005.02.010

Nagase, A., \& Dunnett, N. (2010). Drought tolerance in different vegetation types for extensive green roofs: Effects of watering and diversity. Landscape Urban Plan., 97, 318-327. http://dx.doi.org/10.1016/j.landurbplan.2010.07.005

Nagase, A., \& Dunnett, N. (2012). Amount of water runoff from different vegetation types on extensive green roofs: Effects of plant species, diversity and plant structure. Landscape Urban Plan., 104, $356-363$. http://dx.doi.org/10.1016/j.landurbplan.2011.11.001

Oberndorfer, E., Lundholm, J., Bass, B., Coffman, R. R., Doshi, H., Dunnett, N., ... Rowe, B. (2007). Green roofs as urban ecosystems: Ecological structures, functions, and services. Bioscience, 57, 823-833. http://dx.doi.org/10.1641/B571005

Papafotiou, M., Pergialioti, N., \& Tassoula, L. (2013). Growth of Native Aromatic Xerophytes in an Extensive Mediterranean Green Roof as Affected by Substrate Type and Depth and Irrigation Frequency. Hortscience, 48, 1327-1333.

Provenzano, M. E., Cardarelli, M., Crasso, M., \& Colla, G. (2010). Evaluation of potential green roof plant species in Mediterranean climate. Proceedings of World Green Roof Congress. September 15-16, 2010, London.

Rowe, D. B., Getter, K. L., \& Durhman, A. K. (2012). Effect of green roof media depth on Crassulacean plant succession over seven years. Landscape Urban Plan., 104, 310-319. http://dx.doi.org/10.1016/j.landurbplan.2011.11.010

Sheffield, J., \& Wood, E. F. (2008). Global Trends and Variability in Soil Moisture and Drought Characteristics, 1950-2000, from Observation-Driven Simulations of the Terrestrial Hydrologic Cycle. J. Climate, 21, 432-458. http://dx.doi.org/10.1175/2007JCLI1822.1

Schulze, E. D., Beck, E., \& Muller-Hohenstein, K. (2005). Plant Ecology. Berlin/Heidelberg: Springer.

Stovin, V. (2010). The potential of green roofs to manage Urban Stormwater. Water and Environment Journal, 24, 192-199. http://dx.doi.org/10.1111/j.1747-6593.2009.00174.x

Spala, A., Bagiorgas, H. S., Assimakopoulos, M. N., Kalavrouziotis, J., Matthopoulos, D., \& Mihalakakou, G. (2008). On the green roof system.Selection, state of the art and energy potential investigation of a system installed in an office building in Athens, Greece. Renewable Energy, 33, 173-177. http://dx.doi.org/10.1016/j.renene.2007.03.022 
Thuring, C. E., \& Dunnett, N. (2014). Vegetation composition of old extensive green roofs (from 1980s Germany). Ecological Processes, 3, 4. http://dx.doi.org/10.1186/2192-1709-3-4

Timberlake, K., Carlisle, S., \& Piana, M. (2013). Growing Resilience: Long-Term Plant Dynamics And Green Roof Performance. Proceedings of Citiesalive 11th annual green \& wall conference. San Francisco, October 23-26, 2013.

Townshend, D., \& Duggie, A. (2007). Study on Green Roof Application in Hong Kong. Final Report. Architectural Services Department; Urbis Limited. Retrieved February 2, 2012, from http://www.researchgate.net/publication/258332717_Study_on_Green_Roof_Application_in_Hong_Kong

Van Lennep, E., \& Finn, S. (2008). Green Roofs Over Dublin.A green roof policy guidance paper for Dublin. Draft guidelines for DCC to develop planning directives for the incorporation of Green Roofs in new $\begin{array}{lllll}\text { development. } & \text { Retrieved } & \text { August } & 06, & \text { 2013, }\end{array}$ $\mathrm{http}: / / w w w . s d c c . i e / s i t e s / d e f a u l t / f i l e s / p u b l i c a t i o n s / d c c-g r e e n-r o o f-d r a f t-g u i d e l i n e s-s e p t-2008 . p d f$

Van Mechelen, C., Dutoit, T., \& Hermy, M. (2014). Mediterranean open habitat vegetation offers great potential for extensive green roof design. Landscape Urban Plan., 121, 81-91. http://dx.doi.org/10.1016/j.landurbplan.2013.09.010

Vestrella, A., Biel, C., \& Save, R. (2015). An Experimental Study in Simulated Greenroof in Mediterranean Climate. Journal of Agricultural Science, 7(4). http://dx.doi.org/10.5539/jas.v7n4p95

ZinCo. (2011). Product List. Retrieved August 8, 2011, from http://www.zinco-greenroof.com/EN/downloads/pd fs/ZinCo_Product_List.pdf

\section{Copyrights}

Copyright for this article is retained by the author(s), with first publication rights granted to the journal.

This is an open-access article distributed under the terms and conditions of the Creative Commons Attribution license (http://creativecommons.org/licenses/by/3.0/). 